east of the Habsburg dominions lay the states governed by Vladislaus IV Vasa in the early 1600s. Jacek Zukowski offers an interesting and well-illustrated tour of triumphal entries into several cities in the Polish-Lithuanian Commonwealth by Vladislaus and his queen, Marie Louise Gonzaga.

The best chapters in this volume provide both an intellectual commentary on the festivities' messages and a pragmatic discussion of how they were experienced. As many of these contributors have argued, readers should be aware of the patrons' and organizers' intentions, while also remaining attuned to the realistic experience of events that could be chaotic, misunderstood, underfunded, and unfinished, or a near copy of an event held forty years earlier. Nevertheless, this volume is sound evidence that the field of European festival studies continues to make headway in a multi-disciplinary fashion.

JENNIFER MARA DESILVA

Ball State University

\title{
Oldenburg, Scott.
}

Alien Albion: Literature and Immigration in Early Modern England.

Toronto: University of Toronto Press, 2014. Pp. 290. ISBN 978-1-4426-4719-0 (hardcover) $\$ 65$.

"Strangers," or foreigners, are familiar early modern literary figures of fun. The butt of linguistic jokes and cultural stereotyping, they are set apart as not-English, identified as different through accents, dress, and peculiar mannerisms. Yet, as Scott Oldenburg illuminates in Alien Albion, these outsider characters are often as complexly human and as sympathetically drawn as the English-born-and-bred. In examining historical and literary perspectives on immigrants to sixteenth-century England, Oldenburg asks us to reconsider our critical assumptions about England and the English as inward-looking and xenophobic, defining themselves and their country always against the discomforting difference that surrounds them. Complicating concepts of national identity and nation-formation, he posits instead that we should consider the community as a primary source of identity and association, held together not by geographical boundaries but by shared religious and economic interests, and by the domestic bonds of co-habitation, service, and marriage. Although 
this pre-national subjectivity might be described as parochial, emerging from local guilds and parishes, it is also cosmopolitan and global, embracing an early expression of multiculturalism in which birthplace is only one aspect of commonality.

Oldenburg's primary focus on Protestants, particularly the Dutch and French, provides a compelling case study. These were England's most numerous immigrant populations, set apart by language and nationality but sharing religious beliefs and employment skills with the English majority. Although they experienced official and unofficial discrimination and exclusion, these immigrants, often arriving in England as refugees or exiles from the Continental wars of religion, benefitted from surges of international Protestantism, particularly under Elizabeth I.

Oldenburg's excellent first two chapters lay out ample historical, documentary, and literary evidence for understanding the impact and reception of Continental immigrants under Mary I and Elizabeth. In beginning with Mary, Oldenburg is able to trace a clear divide between the Protestant population in London and their Catholic queen. As he discusses, the first pageants to greet Mary's coronation procession were performed by Europeans, signalling the city's resistance to the queen's anti-alien proclamations, its solidarity with Continental Protestants, and its recognition of the valuable economic and cultural contributions of immigrant communities. While such "sectarian inclusivity" opposed Crown policies under Mary, during Elizabeth's reign the official entrenchment of Protestantism encouraged the strengthening of multicultural alliances. Focusing on the religious and political conditions of the 1560s and 70s, and on the St. Bartholomew's Day Massacre in particular, Oldenburg examines Anne Dowriche's The Frenche Historie and Marlowe's Massacre in Paris. These texts, he suggests, do not simply evoke sympathy for the Huguenots and anger at their oppressors; they also model practices of Christian hospitality and Protestant unity that supported tolerance for a growing population of refugees.

The last four chapters address the tumultuous decade of the 1590s, during which multiple crises-war-weariness, inflation, food shortages-aggravated anti-immigrant attitudes, as many among the native population struggled to survive. As Oldenburg shows, however, prose and dramatic works alike suggested that the English shared not only their faith with Protestant immigrant communities but economic and domestic interests as well. Elucidating what he calls a "provincial globalism" and "worldly domesticity," he postulates that good 
conduct, ethical craft practices, and mutual love and desire were as important as religion in forging ties between foreigners and the English. As his terminology suggests, the multicultural alliances generated by such ties could engender transnational connections that often entirely bypassed the national. It is faceto-face experience that unites people and collapses boundaries and borders, allowing the emergence of new identities and interdependencies.

With the exception of his fifth chapter, Oldenburg structures his analysis around the examination of three authors: Thomas Deloney, Thomas Dekker, and William Shakespeare. Here, he relies particularly on biographical criticism, suggesting that the probable French and Dutch ancestries of Deloney and Dekker, and Shakespeare's documented ties with the London Huguenot community, as well as his own designation as a "stranger" in London, encouraged their more nuanced and compassionate depictions of strangers in their literary works. Although Oldenburg's discerning critical eye continues to generate subtle readings of literary texts, these chapters seem less substantial than the first two, relying perhaps too much on an often speculative uncovering of authorial intention and personal sympathy. As Oldenburg acknowledges, the 1590 s are a complex and fascinating decade. Further use of documentary material would usefully contribute to a deeper and more complex understanding of these literary expressions of pro-immigrant sympathies (or antagonism). While his re-reading of the weavers' petition is an important contribution to Deloney criticism, the most compelling of these chapters is the wayward fifth, in which he examines gender relations and "mixed" marriages, pairing useful historical context with dramatic works by John Marston and William Haughton.

Alien Albion remains, however, a welcome and timely contribution, urging us to rethink the critical predominance of early modern nationhood. In deconstructing concepts of national identity, Oldenburg amply demonstrates the integral role of local and community structures in early modern England. In suggesting that such decentralization also opens up national borders, he reveals the existence of a nascent multicultural globalism that looks forward to the present day.

MADELINE BASSNETT

Western University 